\title{
Review
}

\section{Political theory between philosophy and rhetoric. Politics as transcendence and contingency}

Giuseppe Ballacci

Basingstoke, Palgrave Macmillan, 2018, ISBN: 978-1-349-95292-2

Contemporary Political Theory (2020) 19, S217-S220. https://doi.org/10.1057/s41296019-00314-2; Published online 1 March 2019

Since 2016, we have been living in what are surely exciting times for political theorists, even if they have been very troubling times for liberally minded citizens. The recent political ruptures have opened up new ground, nay, new and urgent need for a renewed political theory. Here I am not referring to the vain Schadenfreude that some scholars of the theoretical persuasion might have momentarily felt when the allegedly more rigorous political science, self-assured in its methods, statistics, graphs and formulas, failed in its predictions of the outcomes of both the UK referendum on EU membership and the U.S. presidential elections. Rather, this failure shows, firstly, that graphs and formulas alone remain insufficient for navigating the web of human interactions, woven by endless combinations of desires, fears, beliefs, and other variables. Perhaps more importantly, it has become quite apparent that much of political theory and philosophy, too, might need to rethink their orientation and priorities, as well as some of their basic assumptions, should they seek to fill this monumental gap in mutual trust and understanding between the experts and the demos - a gap that has become both obvious and urgent to address in our times.

Giuseppe Ballacci's Political Theory between Philosophy and Rhetoric. Politics as Transcendence and Contingency is a significant contribution to preparing this reorientation, and in this sense, could not have been timelier. A major reason for the inability of most political philosophy, political science and public deliberation to meaningfully engage with the political challenges that define our age is, Ballacci argues, their largely unquestioned adherence to the 'hyper-rationalist paradigms' (p. 2), and he proposes to overcome this impediment by recovering a sensibility to the role of the extra-rational in political communication. In this endeavour, Ballacci's explorations celebrate and extend the 'rhetoric revival in political theory' (p. 2), most commonly associated with the work of Quentin Skinner, Maurizio Viroli, and Bryan Garsten. Yet, in a way, Ballacci is more outspoken

(c) 2019 Springer Nature Limited. 1470-8914 Contemporary Political Theory Vol. 19, S3, S217-S220 
regarding the ambitious scope of his argument, which seeks to persuade the reader that the antagonistic relationship between philosophy and rhetoric is expressive of the near-ontological 'tension which lies at the very core of politics: that between the contingency in which politics occurs and the transcendence towards which it strives' (p. 3).

While most contemporary political theory tends to overlook it, or even deny either contingency and/or transcendence any role in reputable political discourse in the first place - and here it would be difficult to disagree with Ballacci's criticism, even if he does not dedicate much space to examples - the book reasserts its significance by exploring a variety of past acknowledgements, perhaps even celebrations, of this very tension. The excavation begins and ends with perhaps the more canonical thinkers of political rhetoric: Plato, Aristotle, Cicero, Quintilian, and at the other end, Hannah Arendt. The second part of the book, where Arendt is more unconventionally preceded by strikingly original interpretations of Leo Strauss and Richard Rorty, thinkers who very rarely figure in this field, in particular distinguishes Ballacci's argument from the abovementioned contemporary revivers of the art of public speaking. The latter tend to centre only on the distant past, leaving us, perhaps, with the impression that this legacy has been (almost) lost. Ballacci, in contrast, highlights the rich, very recent work on the basis of which we can rethink the relation between philosophy and rhetoric, transcendence and contingency in politics anew.

Ballacci's symposium with the more distant past thinkers begins with an account of Plato's paradigmatic critique of rhetoric as demagoguery, as 'verbal dexterity, empty pomposity, triviality, moral ambivalence, and a desire to achieve selfinterest by any means' (p. 13-14) which has, to a large extent, become authoritative for the consequent Western tradition of political thought. Ballacci then juxtaposes Plato's hierarchical dichotomy between philosophy and rhetoric to Aristotle's much more positive revaluation of their relation. He offers a fine and nuanced presentation of rhetoric's political relevance for Aristotle as a mediator between the love of wisdom and love of the city, between the abstract and general principles on the one side, and emotions and partisanship, on the other, between the theoretical and practical reason, as well as of rhetoric as a tool for improving both deliberation and persuasion. Ballacci continues his reconstruction by introducing Cicero and Quintilian, two thinkers for whom the political life - with its defining practices, including the art of public speaking - held an absolutely central position in the strive for human perfection and the good life. Both presented emphatic and elevating cases for what Ballacci calls the 'existential' meaning of citizenship and civic virtue, wherein rhetoric ceases to be merely useful but becomes an art of supreme standing, and which, in Ballacci's presentation, gains in compelling even if only implied - contemporary relevance. Notably, there are no pre-twentieth century modern protagonists in Ballacci's narrative, yet the twentieth century proves to contain plentiful sources for its purposes. The inclusion of the Arendtian

S218 (c) 2019 Springer Nature Limited. 1470-8914 Contemporary Political Theory Vol. 19, S3, S217-S220 
definition of freedom as political action and public speech is in this context almost an imperative, and the book offers an excellent reconstruction of Arendt's defence of politics as the realm whose very existence depends on deliberation, opinions, and persuasion, rather than on the philosophical notions of the truth and transcendence. Far less conventional, and in fact strikingly original is Ballacci's interpretation of Rorty's political thought within this same humanist current that, through the celebration of contingency in human affairs, rehabilitates the art of rhetoric.

I would particularly like to highlight the chapter on Strauss, which proposes one of the most unorthodox and, in my view, one of the few accurate interpretations, not only of Strauss's engagement with the problem of rhetoric and of his conceptualization of the relation between politics and philosophy, but, in fact, one of the most illuminating interpretations of the very structure of his concept of politics in the more general sense. To begin with, it is noteworthy and refreshing that Ballacci refrains from taking sides in the usual post-9/11 ideological battles that largely coloured Strauss scholarship, that is, between the so-called Straussians, mostly conservative, on the one side - who need to prove Strauss's democracyworthiness - and liberal critics of neo-conservatism, on the other, who see Strauss as the latter's founding father. Instead, Ballacci offers an effortlessly clear account of the three key ideas in Strauss's political thought, which I think are newly relevant in contemporary political context, yet which, in much of the interpretative literature and in political theory more generally, tend to either cause embarrassment or provoke accusations of authoritarianism: first, Strauss's insistence on the transcendent character of any truly binding normative horizon in ethics and politics, on the one hand, and second, on the similarly binding role of the political opinion or the 'common sense' of the lay citizen for political philosophy, on the other. Third, Ballacci highlights, quite unlike most of Strauss's interpretations, his unorthodox understanding of rhetoric as the forgotten mediator between the two.

Against the mainstream readings of Strauss as a natural right theorist who advocated a Platonic state ruled by Philosopher Kings, Ballacci's interpretation highlights - in my view, correctly - the strict constraints that Strauss set to the political role of philosophy, and Strauss's criticism of any form of political theory that dismisses citizens' political opinion or their perspective as prejudiced and unscientific. Far from signalling a more practical political philosophy, argued Strauss, deploying opinion and speech as the starting point and limitation to practical imagination opened the way for specifically modern practically intended theoretical utopias. This less known Strauss, furthermore, maintained that, were philosophy to culminate in a final synthesis with action, the latter would not enact a higher stage of philosophy but 'the end of philosophy on earth' (Strauss 2000: 201). Instead of the actualization of philosophy, the idea or striving towards it can result in only one thing: that the 'Final Tyrant presents himself as a philosopher' (ibid:211).

(C) 2019 Springer Nature Limited. 1470-8914 Contemporary Political Theory Vol. 19, S3, S217-S220 S219 
Ballacci correctly notes that, while rhetoric had for Strauss mainly an instrumental and by no means an unambiguously positive role, his critical genesis of its censure is still a compelling starting point in rethinking the fate - and perhaps a renewed role - for rhetoric, between philosophical reason and political action. The book indeed carves out several more such starting points. Yet, in being overwhelmingly interpretational, these starting points remain undeveloped and sometimes only very implicit. In other words, Ballacci unfortunately refrains almost completely from articulating or elaborating on any wider philosophical and political implications of his historical essays, which could have been the subject of a substantial conclusion. That being said, Ballacci's ideas and criticisms nonetheless contain a genuine, even if perhaps too implicit, potential to spark an urgently needed debate on how to rethink and reset the souring relations between those who claim to have expert knowledge in social, political and moral matters, and the adherents of their 'populist' contestants.

\section{Reference}

Strauss, L. (1961) 'Restatement on Xenophon's Hiero,' Leo Strauss and Alexandre Kojève, On Tyranny. Chicago: University of Chicago Press, pp. 177-212.

Publisher's Note Springer Nature remains neutral with regard to jurisdictional claims in published maps and institutional affiliations.

Liisi Keedus

University of Tallinn, Tallinn 10120, Estonia

liisi.keedus@tlu.ee 